\title{
"The Pattern of Opportunities and Challenges of Students Cultivation in Higher Vocational Colleges in the "Belt and Road" Initiative
}

\author{
Zhang Hong \\ Department of School of Marxism, Changzhou vocational Institute of light industry, Changzhou 213164, \\ China
}

Keywords: "The Belt and Road" Initiative; higher vocational colleges; opportunities and challenges; students cultivation

\begin{abstract}
The "Belt and Road" Initiative, not only brings a lot of opportunities for the development of economy and politics, but also brings profound influence for higher vocational education. In the face of these opportunities and challenges, China's higher vocational colleges should seize the opportunity of development in time, promote the optimization and upgrading of the educational structure, enhance cooperation and exchanges with the international community, improve the teaching level and improve their own competitive strength, so as to cultivate more talents for the country. The first part of this paper describes the "The Belt and Road" Initiative, mode of student talents cultivation in higher vocational colleges in our country, and the far-reaching influence. The second part analyzes the "The Belt and Road" Initiative, in the process of cultivating talents in higher vocational colleges to meet the challenges, and analyzes the reasons. Finally, in order to improve the quality of teaching in higher vocational colleges, specific strategic measures are put forward in the face of opportunities and challenges.
\end{abstract}

\section{Opportunities of Talent Cultivation Mode in "The Belt and Road" Initiative in Higher Vocational Colleges}

First of all, "The Belt and Road" strategy and provides a platform for international cooperation for Higher Vocational colleges. China's Higher Vocational Colleges in "strategic development The Belt and Road", a full study of the high level of education in the state of international teaching experience, to enhance the management system, teaching mode, training aspects of learning, international schools often held occupation recreational activities, students exchange activities, enhance China's high The exchange and cooperation between the school and the school in the world. At the same time, we must promote cooperation with other countries in running schools and provide more useful talents for the development of our country. Secondly, it can promote the optimization and upgrading of higher vocational education and improve the quality of education. The strategic target of "The Belt and Road" is to realize our country and the countries along the transport policy communication, China Unicom, trade cooperation and so on, these are our higher vocational education provides more opportunities for development and running space. China's higher vocational colleges can adapt to the development trend of the strategy, meet the needs of the development of the talent market, formulate a targeted training program, set up a scientific curriculum, perfect the teaching system, and promote the optimization and upgrading of Higher Vocational Education in China. Finally, it can improve the international attractiveness of higher vocational education and strengthen cultural exchanges with other countries. From the current point of view, the development of occupation education is becoming more and more popular, in the face of this form, and "The Belt and Road" development strategy, can effectively promote China's higher vocational education internationalization mode, improve the higher vocational education of our country's international reputation, enhance the influence in the international force, so as to promote China's Higher Vocational Education in China International development [1]. 


\section{Challenges of Talent Cultivation Mode in "The Belt and Road" Initiative in Higher Vocational Colleges}

On the one hand, our country is still not paying enough attention to higher vocational education. Most of the investment in education is inclined to the investment in Colleges and universities. Although the standard of higher vocational schools is relatively low, the students can learn the technology and knowledge directly into the construction of the motherland. This makes some higher vocational colleges in China, in addition to maintaining normal school operation, in the absence of excess funds to improve the school running conditions, can not achieve more advanced and fine running level. On the other hand, due to the participation of higher vocational schools in the construction of foreign aid programs and the management of capital use, there is a great limitation in the school infrastructure construction, the dispatch and employment of teachers. There are still many ways for higher vocational schools to go along with the international standards[2].

"The implementation of The Belt and Road" strategy fully demonstrates China as a socialist country of social responsibility and play a big country in the spirit of this strategic guidance, first of all, in the learning content. The higher vocational schools in China can cooperate with other countries along the line to deepen the educational content of the higher vocational schools in our country, so that the higher vocational schools can involve more advanced technology. Secondly, on the whole of running a school. No matter the cooperation of foreign higher vocational education institutions or the separate institutions of higher vocational education, the scale and quantity of educational education in China have been enriched, and the competition of students is more intense. At the same time, it promotes the attraction of higher vocational education to students. Finally, in the background difference. The countries along the line are integrated into the environment of Higher Vocational Education in China. There are many different backgrounds, such as politics, culture, nationality and law. This requires the government to deal with the problems arising from the integration of foreign countries and strictly request the examination. China's higher vocational schools should actively face challenges, advance with the times, improve the content and technical deficiencies of the courses, so as to improve the quality of personnel training.

Higher vocational education in our country at present most professional setting is only suitable for domestic demand, "The Belt and Road" the implementation of the strategy, expanding the range of talent demand, from the construction of new R \& D industry the first industry construction, the most basic of the second industry and the third industry of Science and technology, all aspects need to provide more vocational education Excellent personnel improve the protection of human needs. For example, the construction of high speed rail, language communication in international trade, export of commodities, construction of communication equipment and so on are very popular in the market. This has brought more challenges, pressures and opportunities for higher vocational teachers and higher vocational schools in China. On the one hand, it is necessary for higher vocational teachers to constantly improve their knowledge reserves and the accumulation of actual situation in the industry according to the big direction of the talent demand under the strategy, and adjust the curriculum content. On the other hand, higher vocational schools should strengthen the introduction of talent, the organization of regular teachers' professional knowledge and practical ability training, and cultivate comprehensive quality excellent teachers, the completion of the new period "The Belt and Road" strategic development requirements[3].

\section{Talent Cultivation Mode in "The Belt and Road" Initiative in Higher Vocational Colleges}

The implementation and development of The Belt and Road "strategy, to promote the development of internationalization of our country, enhance the international influence of china. Faced with such a situation, China's higher vocational education should establish an international school running concept and improve the teaching level of higher vocational education. On the one hand, the management personnel of China's higher vocational colleges should set up the thinking of internationalization and promote the transformation of higher vocational education. At the same 
time, the government should also support the government, and combed the consciousness of training talents for the international development. On the other hand, higher vocational colleges should integrate the content of international knowledge into the teaching content, reflect the international thinking in the course of teaching, set up scientific values for the students and improve the comprehensive quality of the students. Therefore, in the implementation of the "The Belt and Road" strategy, China's higher vocational colleges should first establish their own concept of education internationalization, so as to make the basis for optimizing the upgrading of Higher Vocational education.

The quality of teaching is the embodiment of the value of higher vocational education. It is very important for the development of higher vocational education to pay more attention to improving the quality of teaching. Similarly, the education of foreign students should also be paid more attention to improving the teaching level. Therefore, China's vocational colleges should improve teaching methods and improve teaching quality. On the one hand, higher vocational colleges can make full use of their own marketing education knowledge, accounting professional education content, enterprise management education knowledge, engineering manufacturing education content and so on. All aspects of teaching experience and practical skills dig deeper into the role of vocational education, so as to improve and innovate the curriculum education for foreign students. . At the same time, higher vocational colleges should combine theoretical knowledge with practical activities, let students master the content of theoretical knowledge in the process of practical activities, and let students practice in enterprises, enhance the practicality and communicative nature of the teaching, and improve the quality of the teaching quality for foreign students. On the other hand, higher vocational colleges should also enable students to learn language and culture under the influence of culture. The training of Chinese Vocational Colleges for foreign students is mainly to study Chinese language, mainly including learning Chinese vocabulary, grammar, theoretical knowledge, and so on. At this time, Chinese culture class can integrate various cultural contents into the subject teaching. For example, festival celebration culture, diet culture, folk culture and so on, can be used as the cultural background of Chinese language teaching, so that students can more contact Chinese culture in the process of learning Chinese language, so as to promote the spread and development of Chinese culture in the world.

On the one hand, China's vocational colleges should improve the management system for foreign students. There are some problems in the establishment and improvement of the relevant management system in China's higher vocational colleges, which are short of time for recruiting students and lack of certain teaching experience. As the education management of foreign students also involves many other problems, teaching, foreign affairs management, entry and exit management are all related to the education management of foreign students. China's higher vocational colleges should not only abide by various laws and regulations related to it, but also establish and improve the specific management system in Colleges and universities to improve the overall management level of the system of foreign students. China's higher vocational colleges should also set up some relevant systems, such as the management system of foreign students' visa regulations, the management system of student status, the management system of foreign students, and so on, to improve the institutionalized management of foreign students and promote exchanges and cooperation between Higher Vocational Colleges and the international. On the other hand, the management and education of overseas students in higher vocational colleges should be divided into all aspects. Through detailed management contents, higher vocational colleges have made good management quality for students studying and living in Higher Vocational Colleges in China. Because the study of foreign students in the domestic higher vocational colleges will involve many levels of work, so the school should carry out scientific division of responsibility, establish a good management system and provide a good learning environment for the students.

Higher vocational colleges need to develop international teacher training plan. Whether a school has a comprehensive faculty is an important reference for measuring the comprehensive competitiveness of a school. Now in the development strategy of "The Belt and Road", China's higher vocational schools facing the increasingly diversified competition, in the cultivation of 
teachers to change the concept of home, to focus on the internationalization of teachers training. After all, "Belt and Road Initiative" strategy involves background differences in many aspects, only to rely on teachers training and other ways to expand domestic international vision, ability is limited and required a long time, a short time can not meet the general requirements of the development strategy of The Belt and Road ", which requires one aspect of China's higher vocational school focus on Internationalization With the introduction and cultivation of talents, excellent international teachers should be hired to shorten the international gap and promote the transformation of inherent teachers' consciousness and internationalization. On the other hand, China's higher vocational school should actively establish vocational schools and international platform for mutual communication and learning, regular teachers exchange or cooperation is to establish "The Belt and Road" Teacher Training Alliance, made along the countries and between our country and increase educational relations. This can not only improve the overall level of Higher Vocational Education in China, but also help the development of countries and regions with lower education along the line, improve the educational level and highlight the international responsibilities of China. Therefore, in the face of "strategic development The Belt and Road", higher vocational colleges should fully develop the internationalization of teachers' training plan, the development of Higher Vocational Colleges and more scientific teaching way[5].

Actively carry out international cooperation in running schools, and promote China's higher vocational education to the international stage.

"And the rest of the world has brought opportunities for the development of strategic The Belt and Road" for Higher Vocational Education in china. First of all, China's higher vocational schools should open up the sources of funds and the channels of practice, cooperate with Chinese enterprises along the line, establish new sources of funds, and can also cultivate talents suitable for future social needs, and ensure the stability of the output and training of professional talents. It is best to establish a training center with foreign-related enterprises, establish strict international training standards, carry out project follow-up study in the project construction, participate in practice, and become comprehensive talents with strong theoretical knowledge and strong ability in the combination of practice and technical learning. Secondly, in order to popularize the higher vocational education in China, we need to increase the publicity of overseas and open the campus branch, introduce the characteristics of international school, fully respect the cultural background of the local people, set up the required courses and solve the needs of the local talents. Finally, China's higher vocational schools to improve the hardware and software facilities, establish a shared mode to "Internet plus" relying on resources, convenient between domestic and foreign vocational school outstanding technical exchanges, educational experience sharing and allocation of resources, to solve the problems when possible and can also reduce the contradiction. Therefore, China's Higher Vocational Colleges actively carry out international cooperation in running schools, which can effectively promote the internationalization of Higher Vocational Education in China[6].

\section{Conclusion}

"This The Belt and Road" strategy, brings more opportunities and challenges for students of Higher Vocational Education in China's culture. Therefore, in the face of this form, China's higher vocational colleges should set up the concept of international running school, improve the teaching quality in an all-round way, establish and improve the relevant management system, make an all-round development of the training program for the international teachers, and actively carry out the cooperation international running activities, and promote the higher vocational education and education in our country to the international. In the face of the present challenges, there are many shortcomings in the mode of running schools and the training of talents in Higher Vocational Education in China. However, with the continuous development and improvement, it is believed that the teaching quality of Higher Vocational Education in China will be higher and higher, and the international exchange and cooperation will be deepened, and the international level of higher vocational education will be promoted. So as to provide more talents for our prosperity and strength. 


\section{Acknowledgements}

Fund program: Project of Changzhou Higher Vocational Education Research Institute 2017, "One Belt One Road" Strategy for Talent Cultivation of International Students in Higher Vocational Colleges” CDGZ2017030

\section{References}

[1] Yuan-Yuan W U. Reform of Public English Teaching in Higher Vocational Colleges Based on the Background of "The Belt and Road"[J]. Journal of Hubei Correspondence University, 2017.

[2] Cai H. Research on International Cooperation and Communication in Vocational Colleges in the Context of the "Belt and Road" Initiative[J]. Journal of Higher Education, 2017.

[3] Liu G, Sun Y. Research on the Countermeasure for Personnel Training of Higher Vocational Colleges to Boost the "One Belt and One Road" Strategy[J]. Vocational \& Technical Education, 2016.

[4] Ren X J. Research on Education Development and Innovation of Higher Vocational Colleges under the Background of "the Belt and Road"Initiative[J]. Journal of Tianjin Vocational Institutes, 2018.

[5] Zhou P, Li Y. Reflections on the development of Jiangxi Higher Vocational Education "The Belt and Road Initiatives” strategy[J]. Journal of Jiamusi Vocational Institute, 2017.

[6] Wang D D, University U V. Analysis of Challenges of “One Belt One Road” Strategy to Talent Fostering in Vocational Colleges of Xinjiang[J]. Journal of Urumqi Vocational University, 2017. 